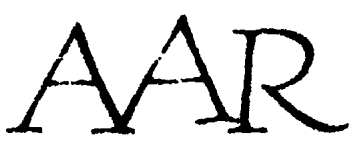

\title{
The Godfather of Psychoanalysis: Circumcision, Antisemitism, Homosexuality, and Freud's "Fighting Jew"
}

Jay Geller

STUDIES OF SIGMUND FREUD'S Jewish identity trace a trajectory from the "ten-or-twelve-year-old" son's shame over his father's submissive response to an antisemitic assault that Freud recalls in his first major work, The Interpretation of Dreams (1900:197), to the opening filial gambit of his last completed work, the only one devoted to an extensive analysis of Judaism and antisemitism, Moses and Monotheism. ${ }^{1}$ Often attempting to psychoanalyze the father of psychoanalysis, these works render that identity as symptomatic of a son dutifully acting out his own ambivalent Oedipal scenario whether with Jacob Freud, Judaism, or European modernity (cf., inter alia, Cuddihy; Robert; Rice; Geller 1997).

Unlike that vast literature, this article examines the impact of Freud's Jewishness from his position as a father and not as a son. The focus of this analysis is one of Freud's classic case histories, "Analysis of a Phobia in a Five-Year-Old Boy," popularly known as the Case of Little Hans. This case, with one notable exception-a footnote in which Freud speculates

Jay Geller is Lecturer in Religious Studies at Vanderbilt University, Nashville, TN 37235.

1 "To deny a people the man whom it praises as the greatest of its sons is not a deed to be undertaken lightheartedly-especially by one belonging to that people" (1939:7). 
on the origin of antisemitism in the castration fears aroused by circumcision-makes no explicit reference to either Judaism or to the Jewishness of all of the individuals involved. Yet, that exception is the synecdochal rule of the text; throughout "Analysis" Freud is working through the problematics of his Jewish identity. After examining the subtexts to the footnote-in particular the situation that led Freud to assume the paternal position in relationship to Little Hans-the article then analyzes how these contexts generated an ethical dilemma that not only may have led Freud to (mis)read the case but also shaped the later development of psychoanalysis. It shows how antisemitism as a living reality for Freud, on the one hand, and circumcision as a general sign and a particular practice performed on a colleague's little boy, on the other, combine with an assimilation-dictated homophobia to construct psychoanalysis's model of individual development and the ideal of the fighting Jew.

\section{A SINGULAR FOOTNOTE}

Sigmund Freud inaugurated the first psychoanalytic journal, the Jahrbuch für psychoanalytische und psychopathologische Forschungen, with a case study that he believed would provide the first compelling case for infantile sexuality as not just "the motive force of all the neurotic symptoms of later life" but as the "common property of all men" (1909a:6). ${ }^{2}$ In his "Analysis of a Phobia in a Five-Year-Old Boy" Freud describes the onset, course, and apparent resolution of a young boy's pathological fear that a " $a$ horse will bite him in the street" (22; emphasis in original); to explicate Little Hans's phobia Freud presents his first full elaboration of the castration complex and the consequences upon individual development of this phantasy that attributes the anatomical difference between the sexes to the penises of some children being cut off. The centerpiece of Freud's paper is the account of Little Hans's phobia and its treatment by his father, a member of Freud's circle; this section consists of the father's weekly reports of observations of and conversations with his son together with Freud's glosses.

Early in the case history Freud identifies the deferred threat of castration-"we are reminded of his mother's old threat that she should have [Hans's] widdler cut off if he went on playing with it" (35; cf. 7-8)-as a likely cause of Little Hans's symptoms. Freud suddenly interrupts his commentary to append an extraordinary footnote that would became the basis of psychoanalytic understandings of antisemitism. It reads:

2 For example, by 1911-12 the writer and philosopher of the German youth movement Hans Blüher (125-126) would employ the case of Little Hans as a proof text of the sexual etiology of neurosis (as well as of infantile sexuality). 
The castration complex is the deepest unconscious root [ Wurzel] of antisemitism; for even in the nursery [Kinderstube] little boys hear that a Jew has something cut off his penis-a piece of his penis, they think-and this gives them the right to despise Jews. And there is no stronger unconscious root for the sense of superiority over women. Weininger (the young philosopher who, highly gifted but sexually deranged, committed suicide after producing his remarkable book, Geschlecht und Charakter [1903]), in a chapter that attracted much attention, treated Jews and women with equal hostility and overwhelmed them with the same insults. Being a neurotic, Weininger was completely under the sway of his infantile complexes; and from that standpoint what is common to Jews and women is their relation to the castration complex. (36n.1)

In sum, hatred of Jews arises as a reaction against "the dreaded castration" evoked by "its symbolic substitute" (1939:91) circumcision. This correlation of castration and circumcision not only undergirds Freud's later elaboration of the causes of antisemitism in Moses and Monotheism, but it informs both some of the earliest psychoanalytic explorations of religious development (Reik 1923) and the most recent psychoanalytic investigations of antisemitism (Tractenberg).

More than stating a psychoanalytic truism about the symbolic relationship of circumcision and castration, the note condenses many of Freud's multiple identity and theory constructions by binding gender, sexuality, and ethnicity/religion/race to the workings of the unconscious, neurosis, and the castration complex. The significance of this footnote is further increased by its anomalous emergence in "Analysis": the body of Freud's text bears no explicit sign of circumcision or other matters Jewish that could have motivated its inclusion. Consequently, in the last decade this footnote has traversed beyond the pages of psychoanalysis to assume an increasing importance in the new historiography of European modernity and especially in analyses of the Jewish identity and identifications of Freud and his fellow Central Europeans. Recent analyses (Gilman 1993a, 1993b; Boyarin) find Freud's nonmention of the Jewishness of Little Hans and, especially, of the convert to Protestantism and closeted homosexual Weininger-as well as of Freud himself-particularly symptomatic of a Freud seeking either to deflect or to displace the implications of being Jewish in early twentieth-century Vienna. Moving beyond the brute facts of the political antisemitism of the Christian Social Party, which under Karl Lueger governed Vienna from 1897, or the institutional antisemitism that limited Jewish professional advancement, ${ }^{3}$ these works (also see Le

3 Freud, for example, held that it was antisemitism that delayed his appointment as a Professor Extraordinarius at the University of Vienna (Gay:136-139). The role of political and institutional antisemitism in Vienna has been explored by many; see, especially, Wistrich; Katz; and Pulzer. 
Rider 1993) situate Freud and his writings negotiating the fin-de-siècle crises of gender, sexual, and ethno-religio-racial identities. Freud himself is seen as more participant than prophet as he endeavors to work through his own situation: the double bind of the Central European Jew. The European society into which many Jews like Freud sought admission demanded complete assimilation to the dominant culture, even to the point of the obliterating of any traces of Jewishness or Judaism; yet, often accompanying the demand was the assumption that Jews were constitutionally incapable of eliminating their difference. Freud, who identified himself with those European values and the corollary objective universals of scientific positivism and enlightenment rationality, was identified by many with the epitome of particularity: the Jew; and a fortiori, psychoanalysis, developed by Freud and preeminently practiced by Jews, was continuously attempting to deflect its identification as a "Jewish national affair" (Freud and Abraham:34).

Freud's texts too are seen as more a symptom of than a remedy for his times. Fin-de-siècle Central Europe witnessed social dislocations, economic destabilizations, growing bureaucratizations, and the collapse of traditional narratives of value and meaning - the old coordinates of identity-as well as the emergence of groups such as women and Jews into the public sphere. Against these threats to the self-proclaimed autonomy and authority of the European subject, popular and disciplinary discourses endeavored to fix an identity to the body, especially to the bodies of those menacing others. Freudian discourse was at least as much shaped by the corporealization of identity as it helped shape this phenomenon. As virtually everything solid melted into air (Berman), the body remained, inscribed with the natural markers of gender, sexuality, race. Identity was read off these inextricably intertwined signs. Jewish identity, in particular, was betrayed by the nose, the foot, the smell, and-because it was of the body-circumcision. The racially coded body revealed its gender and sexuality. This is most pointedly encapsulated in the figure of the circumcised and therefore feminized (male) Jew of questionable sexuality that haunted the Central European cultural imagination (Geller 1993; Gilman 1993a, 1993b; Boyarin).

These personal and cultural subtexts intersect in the footnote. Yet in erecting this footnote as a monument ${ }^{4}$ to an antisemitic, misogynistic, and homophobic modernity and a perhaps "understandably" misogynis-

4 In "Fetishism," Freud (1927:154) writes: "[T]he horror of castration sets up a sort of permanent memorial to itself by creating this substitute" (i.e., the fetish).

5 That is, not only has the East-European-born Jew Sigmund Freud introjected the misogynistic and homophobic norms of the Viennese bourgeoisie in the process of assimilation, but perhaps he has even overcompensated in order to ensure that he passes as a virile and therefore acceptable male 
tic and homophobic Freud, these new studies of Freud's Jewish identity have neglected the relationships of this footnote to Little Hans, to the stakes of Freud's analysis, and to one of the "deepest unconscious roots" for Freud's constructing his theoretical edifice upon the "bedrock" (cf. Freud 1937:252) of the castration complex. Further, there are a number of riddles that also have not been satisfactorily addressed. Perhaps first and foremost, why does Freud allude to-and only allude to-circumcision in the first place? But along with that comes another, perhaps as mysterious: only a year later Freud would undertake his first and most elaborate psychobiography in "Leonardo da Vinci and a Memory of His Childhood." The essay contains an extended iteration of the adventures of our "youthful investigator" (1910:95) to which is appended a footnote that connects castration, circumcision, and the roots of antisemitism; curiously, however, this footnote does not appear until 1919 when "Leonardo" is reissued. In order to unpack the condensations of Freud's original footnote and to resolve these anomalies, this article situates the note in relationship to the arguments of the case history, Freud's relationship to the Graf family, his earlier speculations about antisemitism, and several later writings, in particular, "Leonardo" and the 1919 essay in which Freud incorporates his analysis of his daughter Anna, "A child is being beaten."”

\section{FROM LITTLE HERBERT TO LITTLE HANS}

In 1908 despite a favorable response by some sectors of the psychiatric community, especially Eugen Bleuler and C. G. Jung of Zurich's famed Burghölzli Mental Hospital, psychoanalysis still lacked general acceptance and authority because of its dependence upon the reconstruction of the childhood sexual edifice out of the "débris" of adult pathology (Freud 1909a:6). Confronted by epistemological concerns and moralizing qualms about what Freud considered the incontrovertible hypotheses of his science, he conceded that "even a psychoanalyst may confess to the wish for a more direct and less roundabout proof" (6). When five-year-old Herbert Graf, the son of music critic Max Graf and one-time Freud patient Olga Hönig Graf (Fleming:53), suddenly developed a fear that "a horse will bite him in the street," Freud believed he had found a case to provide such proof. Little Herbert, or as he came to be identified in the "Analysis of a Phobia in a Five-Year-Old Boy," Little Hans, would save the day.

Even before this analysis Little Herbert had already performed yeoman service for the cause of psychoanalysis. His father was an early member

member of his society. On the psychology of the colonized male (or the postcolonized such as Freud; cf. Boyarin), see Nandy. 
of the Wednesday evening group that would become the Vienna Psychoanalytic Society. Thanks to the briefings his father had given to Professor Freud about his son's words and actions, Herbert had made several contributions to the articulation of psychoanalytic theory. In the June 1907 essay "The Sexual Enlightenment of Children" the questions of this "delightful little boy" at age three demonstrated Freud's claim that children's "desire for sexual knowledge shows itself accordingly at an unexpectedly early age" (1907:134). Such "intellectual interest in the riddles of sex" (134) was a crucial component of Freud's theory of universal infantile sexuality. Freud reassuringly adds that "I should like to say explicitly that little [Herbert $]^{6}$ is not a sensual child or at all pathologically disposed" (135). The normality of Little Herbert helped legitimate Freud's theory.

A year later Freud would return to Little Herbert in "On the Sexual Theories of Children." In that essay Freud discusses the theoretical conclusion that Herbert had derived from his data-gathering reported in the earlier piece. Herbert's theory of sexual difference or rather his theory of the absence of the only difference that matters for Freud'-Herbert's "attributing to everyone, including females, the possession of a penis" (1908a:215; emphasis in the original)-is represented as a normal stage of development. In 1923 Freud would himself theorize Herbert's conclusion as the phallic stage in which all children are acquainted with only one organ, the male one (1909a:110n.2). However, in this context Freud's source is no longer the delightful, nonpathologically disposed, then-four-year-old Little Herbert; rather it is an unnamed "five-year-old boy" undergoing analysis by his father. To explain this pathological situation- "the idea of a woman with a penis becomes 'fixated"' ( fixiert; 1908a:216)—which arises from the contradiction between the dictates of Herbert's sexual theory and his perception of sexual difference, Freud introduces a new term, "the castration complex" (217). Freud also propounds the dangerous consequences of a boy fixating upon theory: "he is bound to become a homosexual" (216). Both complex and consequence would play major roles in Freud's working through "Analysis."

Although a number of researchers (e.g., Anzieu; Laplanche) have found adumbrations of the theory of the castration complex in the self-

6 All German editions since 1924 and the Standard Edition (but not the Collier Books edition of The Collected Papers of Sigmund Freud; cf. Freud 1963:20, 21) have substituted Little Hans/der kleine Hans; see editors' addition, Freud 1907:135n.1. While Freud's emendation provides consistency and continuity between this account and the account in "Analysis of a Phobia" (1909a:11 and n.3), it also helps conceal Herbert's identity.

7 As many have commented, Freud's privileging of the penis is already evident in his identification of Hans's term "Wiwimacher" (lit., pee-maker) with the penis. Cf. Silverman; Glenn. 
analysis that culminated in his Interpretation of Dreams, ${ }^{8}$ Freud had not put it together until "Analysis." Fixing upon Hans's "singular remark" (1909a:35) - "It's [i.e., his widdler \{penis\} is] fixed in" (i.e., it's taken root; er ist $j a$ angewachsen; 34 ) - Freud proceeds to uncover "the typical character of the unconscious train of thought which I think is here reason for attributing to Little Hans" (36n.1). The thought is the castration complex. Freud follows that train of thought that, no longer repressed, had now through deferred action ${ }^{10}$ emerged with an accompanying animal phobia. By the end of the analysis Freud intends to have demonstrated the fundamental role of the castration complex in the formation of a normal identity-i.e., male heterosexuality-but at this point in his narrative the threat of castration is first identified as the likely cause of deferred pathological effects and phantasies in one five-year-old little boy.

Now that he is on the trail of a solution to Hans's problems, Freud cannot "interrupt the discussion" (36); still, he does cut away for a moment and offers his readers that most extraordinary footnote in which he associates circumcision with castration. The next section examines the motivations behind this association.

\section{A COMPLEX ADOPTION}

Max Graf writes in his 1942 touching reminiscence of Professor Freud that: "When my son was born [in 1903], I wondered whether it would not be better to have my son brought up in the Christian faith. Freud advised me not to do this. 'If you do not let your son grow up as a Jew,' he said,

8 Also, among the notes collected in the folder "Aus älteren Aufzeichnungen von 1897 an" (from older sketches from 1897 on) Freud (n.d.) writes "Angstfall bei Lektüre Caesar im Gymnasium wegen castra. Kastration. Einengen-Ausschweifen. Keusch u. 'Keusch'??" (Case of anxiety while reading Caesar [Shakespeare's play or Caesar's writings?] in school because of castra[tion]. Castration. Constricting-dissipating. Chaste \& "discreet").

9 The original record of Freud's "Case of Obsessional Neurosis," a.k.a. the Rat Man, reports Freud's reconstruction during the 12 October 1907 session of "how before the age of six [the patient] had been in the habit of masturbating and how his father had forbidden it, using as a threat the phrase 'it would be the death of you' and perhaps also threatening to cut off his penis. This would account for ... the commands and prohibitions in his unconscious and for the threat of death which was now thrown back on to his father" (1909b:263). Freud's notes on the 14 October session indicate that "The ideas that were brought up in [the patient's] mind [at the end of the previous session included]: The idea of his penis being cut off had tormented him to an extraordinary degree" (264). Nonetheless, no mention of castration, complex or simple, made its way into the official account of the case of the Rat Man.

10 Following Laplanche and Pontalis (111), "deferred action" or Nachträglickeit is the "term frequently used by Freud in connection with his view of psychical temporality and causality: experiences, impressions and memory-traces may be revised at a later date to fit in with fresh experiences or with the attainment of a new stage of development. They may in that event be endowed not only with a new meaning but also with psychical effectiveness." The "deferred obedience" discussed below is a form of this psychical process. 
'you will deprive him of those sources of energy which cannot be replaced by anything else. He will have to struggle as a Jew, and you ought to develop in him all the energy he will need for the struggle. Do not deprive him of that advantage" (473). Freud evidently continued to believe in his characterization of a Jew's fate as virile struggle; he wrote in his address to the B'nai B'rith Lodge of Vienna over twenty years later: being Jewish was "indispensable to me throughout my difficult life ... . as a Jew I was prepared to be in the opposition and to renounce agreement with the 'compact majority" (1926:273-274). And the accounts of Freud's earlier life characterize Jewishness as a test of masculinity presented by that antisemitic majority.

The "unheroic conduct" of Freud's father Jacob when assaulted by the Christian lout as a young man together with the son's embarrassed response to his father's submission has become the classic instance of the gender stakes of Jewish identity (see, among many, Boyarin; Cuddihy; Robert). Freud's letters to his fiancée and later wife recount scenes in which he or other Jewish doctors successfully stand up to antisemitic slights and in the process preserve both their honor and the rightness of their position (E. Freud:92-94, 143-144). Perhaps the most graphic depiction of Jewish virility against gentile cowardice appears in Freud's son Martin's memoir of a summer outing in 1901, some two years before the birth of Herbert Graf. He describes how his father confronted a crowd who blocked the way of Martin and his brother Oliver while heckling them with antisemitic abuse: "Father, without the slightest hesitation, jumped out of the boat, and keeping to the middle of the road, marched towards the hostile crowd ... ten men armed with sticks and umbrellas [and] the women remain[ing] in the background, but cheer[ing] on their men folk with shouts and gestures. In the meantime, father, swinging his stick, charged the hostile crowd, which gave way before him and promptly dispersed allowing him a free passage."1 Martin could not have chosen a more "Freudian" account of Jewish gendered identity as Freud the Jew, brandishing his phallic masculinity, had overcome his castrated opponents. ${ }^{12}$ Hence, Freud's charge to Herbert's father to raise his son as a Jew promised him a difficult but ultimately successful development into the early twentieth-century bourgeois ideal of healthy, virile manhood.

Five years after Herbert's birth, however, Freud learns from the father that rather than the strong, self-determined child he had prophesied him to become, young Herbert is in the grips of a phobic neurosis. Initially

11 M. Freud 1983: 70-71. Elsewhere, Martin recalled that afterward his father told them: "We are Jews. You will often have such experiences. Prepare yourself for it in time" (Fraenkel:16).

12 According to Freud (1919b:273), multiple phalli or phallic images symbolize castration. 
Freud locates this turn of events as the deferred effect of the (maternal) threat of castration if Little Hans (i.e., Herbert) continues to masturbate. Yet in the footnote attending that first etiological deduction, Freud evokes circumcision and Otto Weininger, antisemitism and misogyny, none of which appear either before or after the note.

Prompted by his own main text, Freud often inserts aperçus that bear the residue of his outside readings or other everyday encounters (see, e.g., 1909a:98n.1 discussed below, 113n.1 in which he quotes the poet Conrad Ferdinand Meyer, and 131n.1 where he recalls drawings by T. T. Heine). More, however, is attending this footnote than cognitive insight or the chance association of "here a cut, there a cut," the merely contingent fact of Herbert's (unmentioned) Jewish identity or the remains of the Weininger case. ${ }^{13}$ The first link in this note's particular chain of associations is less Hans's singular remark or his mother's recollected threat than it is an event that occurred five years earlier. While Graf does not date his conversation with Freud, ${ }^{14}$ I will take Graf at his word- "when my son was born"-and that as a consequence of the advice of his esteemed friend, Max had his son circumcised. ${ }^{15}$ Unfortunately, instead of producing Herbert Graf, a "muscle Jew,"16 a "fighting Jew" (M. Freud 1967:201) ready to take on the threats of an antisemitic world, the Freud-inspired circumcision had produced Little Hans, a neurotic faygeleh ${ }^{17}$ afraid to enter that threatening world. Because of this possible misstep, the footnote signals that "Analysis" may be more about a "family romance" than it is about the history of a case.

13 Although the controversy over Weininger's alleged plagiarism via Freud and his patient, Weininger's confidante Hermann Swoboda, of Fliess's theory of bisexuality had peaked in 1906, Little Hans's castration anxiety allows Freud to deliver the final salvo in the cycle of recrimination and accusation (see Heller; Le Rider 1982).

14 Pace Gilman (1993a:88), who refers to a question of baptism and suggests that this discussion was epistolary .

15 Does raising his son as a Jew require that Graf circumcise his son? Since 1890 only registration and not circumcision was required for infant (male) Jews under Viennese law. Would Freud have presumed that Herbert was circumcised? According to Rice (1994:251-252 and n.), Freud's three sons were not circumcised. Rice cites a lecture by Peter Swales, an interview with Elliott Philipp (Martha Freud's first cousin, once removed), and Albrecht Hirschmüller's testimony that the records in the Israelitische Cultusgemeinde of Vienna note neither the date of circumcision nor the name of the Mohel, the ritual circumciser, for Freud's three sons. Also cf. Ferris: 379; Gilman 1993b:86: "Freud did not have his sons ritually circumcised" (emphasis added). Nonetheless, if Graf did not have his son circumcised, the allusion to circumcision in this case of a young Jewish boy would only confirm that circumcision is the leit-signifier of Jewishness even in the absence of any empirical sign.

16 Max Nordau, in his plenary talk at the Second World Zionist Conference (1898:72) and more elaborately in "Muskeljudentum" (1900:379-81), invoked the "muscle Jew" as the virile counter to such feminized Jewish types as the atavistic ghetto Jew and the decadent coffeehouse Jew.

17 Yiddish: literally, a little bird; though used as a term of endearment toward a little child, it has the connotation of effeminate homosexual. 
This romance, however, is told from a different perspective than that discussed by Freud (cf. 1908b) - but not testified to by Little Herbert-in the "Sexual Theories of Children." This tale is not told from the perspective of the son who phantasizes that he has been adopted but by the father who, also in the realm of phantasy, has adopted him. In 1908/9 Freud believed that only a parent could analyze a child (Glenn:131); yet not only did Freud directly advise Graf, but Graf's appropriation of psychoanalytic theory mediated his own dealings with his son. His wife's analysis with Freud may too have had an effect. Further, Freud met with Hans during the course of the analysis. He was also viewed by Hans as the ultimate arbiter (1909a:72). Finally, in the face of Max Graf's rather incompetent interpretations of his son's behaviors and phantasies Freud's glosses and discussion also provide analysis - so in a certain way he usurped the paternal role. Still Freud does not just assume the position of father figure in his role as authority and analyst. Rather, by advising Max Graf upon the birth of his son, Freud had (god)fathered Herbert as a Jew; he acted as the kvatter (godfather) who hands the child over to the mohel (ritual circumciser) if not indeed assuming the paternal role of circumciser and binding Herbert to the tradition. "Analysis" is a story that seeks to hide Freud's adoption of Herbert and his responsibility for his condition. Yet to determine the true nature of that condition it is necessary to examine the ensuing connection between (the implicated) Little Hans and Otto Weininger,

In the paragraph to which the footnote is appended Freud describes a "piece of [sexual] enlightenment"18 that supersedes Little Herbert's earlier one: "women really do not possess a widdler" (1909a:36). Freud imagines that in the face of this information Herbert concludes that "it would no longer be so incredible that they could take his own widdler away, and, as it were, make him into a woman!" (36). Sander Gilman (1993b:77) suggests that the footnote is generated because circumcision mediates the new knowledge and the drawn conclusion. Freud's "unstated pattern of thought [is]: if -asks the child-I can be circumcised and my Jewishness revealed, that is, if I can be made into a Jew, cannot I also be castrated and my hidden femininity is [sic] revealed, that is, cannot I be made into a woman?" However, for Gilman Weininger is that child. Gilman asserts that the footnote is one of the stages for Freud's engagements both with Weininger and with the representation of the diseased Jew. It allowed Freud to displace the onus of Jewish difference onto the body of woman (Gilman 1993b; Eilberg-Schwartz).

18 As if rhetorically to reinforce the importance of castration, the translators have here appended the "piece"; the original merely reads "Die Aufklärung" or the enlightenment. 
Admittedly Weininger's text was still a topic of discussion in 1908-1909 (Harrowitz and Hyams), although the significant responses of figures like Karl Kraus (1906:5) or Otto Rank (1981:170-172) were already several years in the past. Its immediate relation to Freud at that moment appears to be incidental. Weininger's name does not appear in Freud's now-extant letters of the time, and there is but one mention of Weininger in the minutes of the Vienna Psychoanalytic Society during the period of the composition of "Analysis." That one mention, however, did occur at a most opportune time: on 1 April 1908 - that is, two days after Freud's one meeting with Herbert Graf during the course of the analysis and therefore perhaps a week after Max Graf's report that would in "Analysis" provoke the footnote on Weininger-the Wednesday evening group met to discuss Nietzsche's "On the Ascetic Ideal" (part three of the Genealogy of Morals). The minutes report that Paul Federn remarks, "It is worth mentioning that Otto Weininger also had to struggle with the suppression of sadism (ideas of lustful murder); his book shows him to be a highly ethical individual" (Nunberg and Federn:359). Although the content of Federn's comment is not reflected in Freud's note and while we cannot assume that the footnote and accompanying commentary originates with the receipt of Max Graf's report, the mention of Weininger may nonetheless be part of the day's residues that attached to Freud's analysis. Despite this intriguing coincidence and not to deny Gilman's train of thought, still the appearance of Weininger in this note has more to do with the profound concerns that Little Hans's sexuality aroused in Freud.

\section{ACCESSING HANS'S HOMOSEXUALITY}

The trail of associations begins in the commonality of the characterization of Weininger and Little Hans: "highly gifted but sexually deranged." 19 Throughout "Analysis" Freud comments on Hans's insight: "Hans, with his usual acumen, had once more put his finger upon a most serious problem" (1909a:91n.1). Earlier Freud speaks of how Hans "had worked out glosses upon the many difficulties involved in the stork hypothesis" (74n.1); or when Hans sees through his father's rationalizations and argues for the value of a patient's thoughts for therapeutic understanding, Freud comments, "Well done, little Hans! I could wish for no better understanding of psychoanalysis from any grown-up" (72n.1). But Hans is also "sexually disturbed." The agon of Hans's case for Freud lay not in the angst

19 This characteristic was also shared by the subject of another case history, Senatspräsident Schreber (Freud 1911).On Freud's positive valuation of (and possible identification with) Schreber, see, inter alia, Freud 1911:79; Santner; Geller 1994. 
aroused in the young boy by the horse's penis but in Hans's sexual orientation. In "On the Sexual Theories of Children" Freud would indicate the consequences of fixating on the existence of the maternal penis: the little boy was "bound to become a homosexual" (1908a:216). For Freud, every child at a certain stage is homosexual (cf. 1909a:110); hence, when Freud notes Hans's first trace of homosexuality, adding as well that "it will not be the last" (cf. 14), he light-heartedly comments with paternal irony meant to tweak the noses of his gentile readership that "Little Hans seems to be a positive paragon of all the vices."

Yet it is important for Freud that this be a stage that is overcome. "In his subsequent development, however, it was not to homosexuality that our young libertine proceeded, but to an energetic masculinity with traits of polygamy" (110). He became a "true man" (ein rechter Mann; 17) and a "little Oedipus" (111). After this neurotic deviation Little Hans reassumed his destined role: heroic manhood characterized by virile heterosexuality. ${ }^{20}$ Unfortunately the case belies that conclusion. As proof of Hans's polygamy Freud comments that "The sexual aim which he pursued with his girl playmates, of sleeping with them [bei ihnen zu schlafen; emphasis Freud's $]^{21}$ had originated in relation to his mother. It was expressed in words which might be retained in maturity though they would then bear a richer connotation" (110-111).

Little Hans, however, does not employ this sexually connotated phrase, sleeping with or schlafen bei, with regard to his girl playmates during his "subsequent development." Rather, he uses it during that period prior to the onset of his phobia (cf. 16-17) when, as Freud had just put it, "Hans was a homosexual" (110; cf. 17: "accesses of homosexuality" [homosexuellen Anwandlungen=homosexual impulses]). The phrase (i.e., "sleeping with") only recurs near the conclusion of the case history, and then both boys and girls are sleeping with him. Hans is discussing "his children" (93; quotation marks in the original) with his father. When his father asks him what he did with the children, Hans replies that "I had them to sleep with me, the girls and the boys" (Bei mir hab' ich sie schlafen lassen, Mädeln und Buben; 94). And then in response to his father's questioning about where these children came from, Hans manifests his phantasy/desire of being a mother and giving birth (94-95):

20 In "Leonardo" Freud writes: "Indeed it almost seems as though the presence of a strong father would ensure that the son made the correct decision in his choice of object, namely someone of the opposite sex" (1910:99).

21 Interestingly, when Hans employs the phrase, the love objects are always sleeping with him (bei mir schlafen), not he with them. Little Oedipus remains more Little Narcissus. 
I: "But who did you think you'd got the children from?"

Hans: "Why, from me."

....

I: When you sat on the chamber and lumf came, did you think to yourself you were having a baby?

Hans (laughing): "Yes...."

The day before this conversation Hans had already expressed his desire to be a mother: "And Daddy, until [bis] I'm married I'll only have one [baby] if [wenn] I want to, when [wenn] I'm married to Mummy, and if [wenn] I don't want a baby, God won't want it either, when [wenn] I'm married" (92). The translation in the Standard Edition effaces that desire by reading bis (until) as "when." By shifting the temporal reference and placing Hans in the position of the father, the editors clear up Hans's somewhat convoluted statement and in the process echo Freud's subsequent (i.e., in the text, not in the time of writing) dampening of any suggestion of Hans's effeminacy. In anticipation of the ensuing revelations of Hans's phantasy life, Freud (93n.1) felt compelled to offer in his footnotes the reassuring gloss that "There is no necessity on this account to assume in Hans the presence of a feminine strain of desire for having children. It was with his mother that Hans had had his most blissful experience as a child, and he was now repeating them, and himself playing the active part [i.e., the masculine], which was thus necessarily that of mother." If this preemptive commentary was not sufficient to distract the reader from "the presence of a feminine strain," then his discussion of Hans's expressions would complete the job. Thus, Freud takes Hans's claim that his children come from himself as signifying: "They were the children of his phantasy, that is to say of his masturbation" (94n.2). With these glosses Freud sets up his readers to ignore Hans's own testimonies of desire and prepares them to accept the screen history of resolved neurosis and normal sexual development Freud would generate in his subsequent discussion of the case (cf. Rudnytsky).

Freud's ultimate denial of Hans's ongoing homosexuality occurs in (mis)interpreting Hans's second plumbing phantasy with which his father's report concludes: "The plumber [Installateur] came; and first he took away my behind with a pair of pincers, and then gave me another, and then the same with my widdler" (98). Hans had initially dreamed about the plumber several weeks earlier: "I was in the bath, and the plumber [Schlosser] came and unscrewed it [i.e., his widdler]. Then he took a big borer [Bohrer] and stuck it into my stomach" (65). As to the adequacy of the father's Oedipal translation of the initial phantasy-the big paternal penis kicking the son out of the maternal bed-Freud notes: "Let us suspend our judgment for the present" (65). With the return of the plumbing 
phantasy Freud too seems to hold back. He allows Hans's father to interpret this second phantasy as Oedipal wish fulfillment: Hans wants to be like his Daddy. Freud then applies his own happy spin on the event: "With Hans's last phantasy the anxiety which arose from his castration complex was also overcome, and his painful expectations were given a happier turn" (100).

In the guise of mere scholarly speculation Freud offers some commentary on Hans's phantasies in a note.

Perhaps, too, the word 'borer' [ 'Bohrer'] was not chosen without regard for its connection with 'born' ['geboren'] and 'birth' ['Geburt']. If so, the child could have made no distinction between 'bored' ['gebohrt'] and born ['geboren']. I accept this suggestion, made by an experienced fellowworker, but I am not in a position to say whether we have before us here a deep and universal connection between the two ideas or merely the employment of a verbal coincidence peculiar to German. Prometheus (Pramantha), the creator of man, is also etymologically 'the borer.' (Cf. Abraham, Traum und Mythus, 1909). (98n.1)

This word play would return in the discussion section; there it becomes the key to interpreting not only these phantasies but the entire network of Oedipal symptoms and phantasies. Freud deduces that "The big bath of water, in which Hans imagined himself, was his mother's womb; the 'borer,' which his father from the first recognized as penis, owed its mention to its connection with 'being born"' (128). Consequently, Freud now recognizes that first plumbing phantasy as a "phantasy of procreation, distorted by anxiety" (angstenstellte) that requires what Freud qualifies as a "very curious" interpretation: "With your big penis you [i.e., his father] 'bored' me [i.e., gave birth to me; Freud's interpolation] and put me in my mother's womb" (128). Armed with this combination of word association and reconstructed thought, Freud traces Hans's phantasy back to the crisis precipitated by the birth of his sister: "He was faced with the great riddle of where babies come from, which is perhaps the first problem to engage a child's mental powers, and of which the riddle of the Theban Sphinx is probably no more than a distorted version" (Entstellung; 133). This riddle of where his sister comes from and in particular the questions of the role of his father and his father's widdler in her production as well as the matter of his mother's imagined widdler together precipitate the entire Oedipal scenario with its accompanying castration complex.

Yet Freud's trumpeting the phonic association between bohrer and geboren seems a "very curious" move when the manifest phantasy clearly portrays a different scene of "passive-feminine identification" (Silverman:109, 115; Frankiel; De Carvalho-Ribeiro; Cournut-Janin and Cournut: esp. 1374-1381, 1443-1444) with his mother and desire for his father. 
Little Hans is being penetrated by his father's penis. The refusal of Freud to draw this conclusion is all the more curious in light of Hans's father's interpretation of his conversation with his son just after learning of the plumber phantasy and of Freud's own comment on that interpretation. Father and son talk about the sound of lumf falling, after which Hans's father offers the interpretation that his (i.e., Hans's) "fear of defecation and his fear of heavily loaded carts is equivalent to the fear of a heavily loaded stomach" (66). Freud comments that "In his roundabout way Hans's father was beginning to get a glimmering of the true state of affairs," namely, that the object of Hans's concern-and phantasy-was procreation. Freud would point out that Hans had made the connection between his mother's groans of pain $(10$; $\mathrm{cf} .133)$ and the birth of his sister, that he had developed and had adopted the infantile excremental theory of childbirth (cf. 74-75), and that he desired to and thought he could have a child (86-87). Freud had already recognized the love that Hans felt for his father; Freud there contradicted Hans's father who obdurately asserted Oedipal hostility in the face of his son's protestation: "Why did you tell me I'm fond of Mummy and that's why I'm frightened, when I'm fond of you" (44). Yet Freud neither noted the negative Oedipal situation then $^{22}$ nor did he recognize that in this phantasy of procreation Hans was phantasizing about replacing his mother and bearing his father's child.

This (mis)recognition of Hans's maternal identification is clearly indicated in a slip that the editors of the Standard Edition attempt to gloss over; it occurs during Freud's discussion of Hans's phantasy of the two giraffes, one big and the other crumpled. Initially Hans had argued that the former was his mother and the latter his baby sister; eventually Hans accepts his father's interpretation that the big one is him (i.e., the father) and the crumpled one his mother (cf. 40). When deducing that the choice of the giraffes derives in part "perhaps, by an unconscious comparison based upon the giraffe's long, stiff neck," Freud adds in a note that "Hans's admiration [Bewunderung] of his father's neck later on would fit in with this" (122 and $\mathrm{n}$.). The only reference to a neck in the text is, however, to his mother's; in accepting his father's interpretation of the identity of the giraffes, Hans had demurred over his father's anatomical explanation. When his father suggests that the long neck (of the big giraffe) reminded

22 Nor later. In his reconsideration of the case in Inhibitions, Symptoms and Anxiety, Freud contrasts Little Hans's "'positive' Oedipus complex" with the Wolf Man's inverted one (1922b:107, cf. 124); pace Freud, see Garrison on Little Hans's “'negative' Oedipus complex". In the interim (1922) Freud had met the grown-up Herbert Graf, "a strapping youth of nineteen [who] declared that he was perfectly well, and suffered from no troubles or inhibitions" (1909a:148). Graf would later marry (twice), have a child, and become a leading opera director in both Europe and the United States (Strauss and Röder:411). 
him of a penis, Hans replied: "Mummy has a neck like a giraffe, too. I saw, when she was washing her white neck" (40). The editors suggest that Freud was condensing that scene with a later one in which Hans comments on how white his father's bared torso is (53). Hans's original gloss on the giraffe scene can, however, more readily be read as expressing his continued belief in the maternal penis and in his sister's "still quite small" one (11).

Freud's slip with its reference to Hans's affect shifts the register from the cognitive to the sexual; the father becomes an object of desire. Consequently, rather than having resolved his castration complex and moved on to latency and "normal" psychosexual development, Little Hans had maintained his "homosexual accesses." Hence, what Freud could not say in his text, but which the text more than testified to, namely, Little Hans's persistent homosexuality, emerged with the footnote on antisemitism and Weininger. Whereas Hans's "fixed in" penis had led Freud to recognize the deferred action of castration anxiety, ${ }^{23}$ perhaps Hans's "fixation" on the maternal penis led Freud, because of its telos of homosexuality (cf. 1908a: 216), ${ }^{24}$ to associate him with the sexually deranged Weininger who was under the "sway of his infantile complexes." Perhaps with this apposition of Little Hans and Weininger Freud acknowledges what he would more explicitly state, albeit in the form of a general proposition, in the previously published but apparently later composed "On the Sexual Theories of Children": namely, the homosexual consequences of Hans's fixation. That is, if, as Gilman (1993b:77) and Boyarin (238n.60) suggest, Herbert's circumcision mediates either visually or ideationally the recognition of castration, ${ }^{25}$ then by advising Max Graf to raise his son Jewish-in effect, to circumcise his son-Freud had from his perspective condemned Herbert not just to neurosis but to homosexuality. Hence, in including the footnote Freud is probably less concerned about countering the general association of Jews with homosexuality (cf., inter alia, Mosse: esp. 68-70) - although this can also be adduced, since for many Weininger assumed an exemplary status of Jew as homosexual ${ }^{26}$ - than he is with

23 Hans's language choice- "It's fixed in" (er ist ja angewachsen), the "singular (sonderbare) remark" which Freud fixes upon, repeating it twice after reporting Hans's father's account of it-may also have contributed to the appearance of the footnote. Freud may have associated uncovering the significance of the penis that has "taken root" (i.e., angewachsen the term translated as "fixed in" is defined in the Wahrig Deutsches Wörterbuch as "Wurzel geschlagen") with uncovering the "deepest unconscious root" [Wurzel] of antisemitism and misogyny.

24 Or conversely, since "Sexual Theories" was written while "Analysis" was probably in page proofs (cf. editor's note 1908a:207), perhaps this ascription of a homosexual telos was Freud's afterthe-fact recognition of Hans's persistent homosexual accesses.

25 Would Hans have realized that he was circumcised? See $n$. 34 below.

26 Moreover, acknowledging the relationship between Hans's (or Weininger's) homosexual impulses and the persistent castration anxiety generated by his own circumcision risks generalizing 
more particular and personal matters. ${ }^{27}$ By interpolating Weininger and circumcision into his case study Freud the paternal advisor (the paternal surrogate and circumciser) signals his sense of responsibility for Hans's neurosis and homosexuality, while Freud, the circumcised analyst, troubled over his own conflicted "homosexual accesses," ${ }^{28}$ indicates his identifications with Hans the investigator.

\section{THE ROOTS OF THE FOOTNOTE}

The assumption has been that the note's speculation about antisemitism emerged out of the condensation of the thought of castration and the displaced ethno-religio-racial and sexual identities of Little Hans and Weininger. Freud had not in his earlier published writings theorized a genetic (or any other beyond the empirical) understanding of antisemitism. Yet among the Nachlass in the Sigmund Freud Collection at the Library of Congress is a folder of notes on assorted subjects, the first page of which bears the rubric "Aus älteren Aufzeichnungen von 1897 an" (from older sketches from 1897 on). Attached to the second page of the folder is a sheet containing a note entitled "Eine Quelle des Antisemitismus" (a source of antisemitism). It reads: "The fact that anti-S[emitism] is generated in the nursery [Kinderstube] is clear. Irma has a physical horror of any Jew. When she was a child they said (in Ofen [=Buda, Hungary]), if there was any trace of Incontinentia alvi [i.e., fecal incontinence] on a child's vest: the Jew has wiped [abgewischt] his mouth on it again."29 Aspects of this earlier speculation share much in common with the later theorization and its accompanying case study and indeed may have provided a template for Freud's later thoughts. Both theories share a common origination for antisemitism in the nursery (Kinderstube). And each is generated through the mediation of a famous patient of Freud's. Since Freud apparently had no patient by the name of Irma at that point in his career, the "Irma" of this earlier note may very well be one of the women who together formed the Irma of the specimen dream (Traummuster). That dream, also known as the "Dream of Irma's Injection," was the first, Freud claimed, upon which he systematically subjected every detail to free

the phenomenon for all circumcised Jewish males and thereby confirming the stereotype (Geller 1993; Gilman 1993b; Boyarin).

27 The move from castration to circumcision, the sign of Jewish difference, may also betray Freud's attempt to universalize Jewish particularity.

28 A significant literature has grown over Freud's homosexuality/homophobia; see, e.g., Koestenbaum; Boyarin; Davis.

29 Cit. Grubrich-Simitis:111-112. In "The Remains of the Day: Weisswashing the Dream of Irma's Injection" (Geller n.d.), I argue that the Irma of this note may be Ilona Weiss or, as she is known in the Studies in Hysteria, Elisabeth von R. 
association and analysis; in the process he came to realize that wish-fulfillment was the rationale for dreams. ${ }^{30}$

More significant are the remarkable parallels between the components of "Eine Quelle" and the details of Hans's case history. The note from the folder suggests that anti-Jewish sentiment is tied to the perception of the Jew's deviant sexuality: specifically annilingus, but the note also implicates other forms of oral sex such as fellatio and cunnilingus as well as olfactory fetishism exemplarily enjoyed by the (Jewish) renifleur. ${ }^{31}$ The association of Jews with dirt and excrement is also clearly invoked. There is a third field of anti-Jewish representation: the Jew as ass-licker, Arschlecker, or the fawning flatterer, the Schmeicheler, of those in power. These elements have all been picked up in later psychoanalytic and psychological interpretations of antisemitism (Horkheimer and Adorno; Rubenstein; Grosser and Halperin), and all three of these figures pervade "Analysis." To English readers of the text the first two-deviant sexuality ${ }^{32}$ and excrement-are manifestly, even obsessively, represented. The third is no less pervasive and is heavily invested with sexual content. Hans manifested his desire for his mother by coaxing with her; for example, "When I was asleep I thought you [i.e., his mother] were gone and I had no Mummy to coax with." A note adds that "coax" was his expression for "caress," and the German word translated as "coax" is "schmeicheln." Hans was a ready Schmeicheler; forms of the term appear at least ten times during the course of Freud's narrative. Shared by both the Jew figured in the earlier note and Little Hans, these characteristics would transform Hans into "Itzig"-the

30 In "The Remains of the Day" I detail a series of connections between the case of Ilona Weiss and the Irma dream.

31 Cf. 1909b:295 on the Rat Man as renifleur. His therapy preceded that of Hans. On renifleurs, see also 1905a:155n.

32 Not just deviations with regard to object like homosexuality but also with regard to aim such as is manifest by oral sexuality. Although in his analysis Freud focuses upon penile penetration of the lower body, oral sexuality plays a prominent role. When Freud first introduces Hans's widdler, he makes a curious association in order to, in effect, sustain his never questioned identification of Wiwimacher with penis and thus to maintain his claim for the existence of the castration complex. He cites Hans's "innocent" question, "Mummy, have you got a widdler too?" and her fateful answer, "Of course"-fateful because this initiates the chain of misunderstandings that make viable the castration threat. Then he notes Hans's identification of a cow's udder as its widdler. Yet to adduce Hans's typicality Freud adds as evidence: "I once put forward the view that there was no need to be too much horrified at finding in a woman the idea of sucking at a male organ. This repellent impulse, I argued, has a most innocent origin, since it was derived from sucking at the mother's breast" (7). Of course, Hans's primary phobic representation is the horse biting off Hans's widdler. One might also locate here another remainder of Freud's repression of Hans's homosexual reserve. During this period Freud would draw upon "udders," whether goat or cow, to signal the connection between castration and deviant sexuality. For example, in his analysis of Schreber (1911:34) Freud employs Kant's simile of milking a he-goat; see Geller 1994:184-186. Freud's non-necessary resort to the everyday with his bovine example suggests to Madelon Sprengnether (62-63) Freud's utter failure to efface the traces of another repression, that of the important role of the preoedipal mother. 
model of the clever, cheeky, and nosy Jewish boy who knows the facts of life. ${ }^{33}$ Given these correlations between the language of the notes, on the one hand, and between the representations of the Jew and of Little Hans, on the other, recollection of the earlier note or its accompanying ideas may well have drawn Freud's attention to a connection between Herbert's situation and antisemitism. ${ }^{34}$

Yet Freud does not trace the connection along the lines implied by the note; rather, the nature of the case-as well as the history of Jewish representation (see, e.g., Gilman 1991; Geller 1993) - condenses the panoply of Jewish characteristics upon the circumcised penis. It was the foremost marker of male Jewish identity. Further, for Freud to have pointed out Hans's Jewishness would have implicated him in Hans's dilemma because of his earlier counsel; hence Freud needed to displace the attribution of Jewishness from a property of the body of the concerned to the gaze and imaginary of the non-Jew.

There were other factors at work not only in Freud's silence about the Jewishness of the dramatis personae but also in the descriptive yet nonetheless oblique reference to circumcision. During this period in which he was working on "Analysis" Freud was concerned about any associations between psychoanalysis and Jewishness. The day after Hans's concluding plumber phantasy (3 May 1908), Freud writes to Karl Abraham about the value of Jung's association with the Vienna Psychoanalytic Society: "I nearly said that it was only by his appearance on the scene that psychoanalysis escaped the danger of becoming a Jewish national affair" (Freud and Abraham:34). Freud's concern is less the membership than the

33 Around the time Freud was writing up the case history of Little Hans, Freud told the following joke to Theodor Reik: "The boy Itzig is asked in grammar school: 'Who was Moses?' and answers, 'Moses was the son of an Egyptian princess.' 'That's not true,' says the teacher. 'Moses was the son of a Hebrew mother. The Egyptian princess found the baby in a casket.' But Itzig answers: 'Says she!'” (cited by Yerushalmi:1, who deduces 1908 as the time of its telling from Reik [1954: 18]).

34 One other overlap between the earlier note (i.e., "Eine Quelle") and the case study leads to a further speculation about the connection between Hans's situation and antisemitism. The last message that Hans wishes to share with the Professor (i.e., Freud) is how that morning (1 May) he had wiped (ausgewischt; emphasis added) the behinds of his phantasy children. He had done this, he informs his father and the Professor, because he would like to have children and when they came he would clean (abputzen; emphasis added) their behinds. He also wanted the Professor to know that when he did lumf and widdled in the W.C., the children had looked on (zugeschaut; 97); Hans had earlier described how Berta, the Gmunden landlord's child, had always watched him widdle (zugeschaut, 60-61; cf. 21 where Olga, Berta's sister, joined in the audience; 32 where Grete, another Gmunden friend, also is reported to have been shown Hans's widdler). The juxtaposition of Hans's wiping lumf with the public uncovering of his Jewishness recalls the scene of the earlier note within a new situation in which circumcision is the foremost Jewish trait. This construction of Hans's message suggests that the earlier note had come to mind when Freud had perhaps been informed that either Hans (i.e., Herbert Graf) had been the object of antisemitic taunts from his gentile friends or his Jewish difference had been pointed out to him during his public urinations while staying at Gmunden. 
perception of a particular Jewish character to psychoanalysis. ${ }^{35}$ The importance of Jung as a buffer against antisemitic judgments of psychoanalysis is reiterated in another letter to Abraham that Freud sends later that year (26 December 1908) as he is about to publish his case history of Little Hans. Afraid that "Analysis" will create an uproar, Freud wryly comments: "German ideals threatened again! Our Aryan comrades are really completely indispensable to us, otherwise psychoanalysis would succumb to anti-Semitism" (64). ${ }^{36}$ With the "defensive din"-antisemitism-of his German readership Freud anticipates a confirmation of the scenario of castration threat and ensuing neurosis played out in the footnote in "Analysis."

Granted that his readership already identifies Freud as Jewish, would overt references to the Jewishness of his patient or an explicit reference to the Jew-associated circumcision (Beschneidung) have exacerbated the situation? Curiously, the term does not appear in Freud's published work until after the loss of his gentile cover, i.e., the breakup with Jung. Indeed, it then appears, albeit only in a footnote and without any explicit Jewish reference, in the text which signaled that break, Totem and Taboo. ${ }^{37}$

\section{LIKE DAUGHTER, LIKE SON}

"Circumcision" does appear in a work written a year after "Analysis," namely, "Leonardo da Vinci and a Memory of His Childhood," but, as already mentioned, that passage was actually added in 1919. The opening sections of "Leonardo" extensively rehearse Freud's earlier arguments from "The Sexual Theories of Children" and "Analysis." Setting the stage for Freud's discussion is a notorious mistranslation. In naming the crucial figure in the memory of the essay's title, the German translator of Merezhkovsky's biographical novel Leonardo da Vinci, Freud's primary source, employed Geier, vulture, for the korshun, Russian for kite, that "opened [baby Leonardo's] mouth with its tail and struck [him] many times with

35 Freud's concern here is double. Not only is he wary of the repudiation of an antisemitic public, but the judgment of particularity would disqualify psychoanalysis from making any universal, i.e., scientific, claims.

36 Freud is referring to the discussion of sexuality in general and childhood sexuality in particular. Six weeks earlier (10 November 1908) Abraham had written to Freud describing the reaction to his interventions at a meeting of the Berliner Gesellschaft für Psychiatrie und Nervenkrankheiten: "I had, inter alia, mentioned Konrad Ferdinand Meyer ... as an example of love for the mother. That was unheard of. German ideals were at stake. Sexuality was now even attributed to German fairy tales, etc." (Freud and Abraham:56).

37 "When our children come to hear of ritual circumcision, they equate it with castration.... In primaeval times and in primitive races, where circumcision is so frequent, it is performed at the age of initiation into manhood and it is at that age that its significance is to be found; it was only as a secondary development that it was shifted back to the early years of life ..." (Freud 1912-13:153n.1). 
its tail against [his] lips" (1910:82). Whereas a kite's tail is just a kite's tail, the mythological associations tied to the vulture proved more conducive to Freud's interpretation of Leonardo's fellatio-suggestive phantasy. Ancient natural historians believed the latter bird of prey only to exist as female; hence the Egyptians employed the figure to symbolize both motherhood and, more significant for Freud, the androgynous (i.e., penis-bearing) mother goddess Mut.

Freud extrapolates from this mistranslation-driven phantasy of the maternal penis to an understanding of Leonardo's later development of "manifest, if ideal [sublimated] homosexuality" (1910:98) by way of a long discussion of childhood curiosity about "the riddles of sexual life," the "youthful investigator's" belief in the maternal penis, the obsession with his own penis, and the castration complex that directly and indirectly alludes to Little Hans's experience (95-96). When discussing the castration complex, Freud brings up the misogyny that in "Analysis" he had relegated to a footnote: "Under the influence of the threat of castration he now sees the notion he has gained of the female genitals in a new light; henceforth he will tremble for his masculinity, but at the same time he will despise the unhappy creatures on whom the cruel punishment has, as he supposes, already fallen" (95). It is at this juncture that some nine years later Freud would append the footnote on circumcision and the unconscious roots of antisemitism. Freud then adds one more genetic factor into the mix of interpretations. His argument moves from viewing women as objects of contempt to a much different-yet complementary-relationship. In "Leonardo" Freud first recognizes what he pointedly ignores in "Analysis": the role of maternal identification in the development of homosexuality.

If we may assume that in 1910 Freud was concerned with distracting his audience from Jewish associations in his work, then despite the extensive rehearsal of his arguments from "The Sexual Theories of Children" and "Analysis," the omission of circumcision as well as its relation to castration and antisemitism would be in order. Indeed, discussing the connection among these was as apparently extraneous to the argument in the main body of "Leonardo" as in "Analysis". Given that the addition of the footnote did not provide additional support for his argument, why then did Freud insist on appending a footnote about circumcision to the discussion of Little Hans's experience in the reissue of "Leonardo" in 1919? There were events that year such that through some form of "deferred obedience" (1909a:35) Freud recognized again the pertinence of the footnote to Little Hans's narrative.

In 1919 Freud was working on his essay on the "Uncanny." His analysis revolves around a topic prominent in the case of Little Hans, namely, the castration complex, as well as includes a long footnote on the male 
feminine attitude and the identification of a male self with a female (automaton or doll). It also examines two themes that played a role in the return of the footnote: repetition-compulsion and the Doppelgänger. More significant, Freud's own professional practice may have elicited from him his own experience of the uncanny as he had recently taken on a patient whose case he would discuss in "A Child Is Being Beaten" and whose case has definitive echoes of Little Hans's. That patient was Anna Freud.

Freud's daughter had most likely played a minor role in the account related in "Analysis." Hans's father had successfully employed the mention of the Professor's "very pretty little girl" (1909a:33) to lure Hans to the Professor. ${ }^{38}$ This gambit, which would attest to Hans's heterosexual "accesses," opens the section "Weekly Report from Hans's Father." Freud's commentary on the report culminates with the footnote on circumcision. Eleven years later Anna Freud was making her own visits to her father's office. She was troubled by her inability to decide among life options: should she adopt the more traditional female role of teacher, albeit one informed psychoanalytically, or should she follow in the footsteps of her father and become a psychoanalyst? During the course of her analysis she discussed her beating phantasies. In "A Child Is Being Beaten" Anna Freud is not mentioned by name; however, the "fifth patient, who had come to be analyzed merely on account of indecisiveness in life, would not have been classified at all by coarse clinical diagnosis, or would have been dismissed as 'psychasthenic"' (1919a:183) is generally considered to be Freud's daughter. ${ }^{39}$ Several years later she would herself write of her own beating phantasies in "Beating Fantasies and Daydreams."

At the outset of his analysis Sigmund Freud describes the generic development of his patients' beating phantasies: "the phantasy has feelings of pleasure attached to it.... At the climax of the imaginary situation there is almost invariably a masturbatory satisfaction-carried out, that is to say, on the genitals. At first this takes place voluntarily, but later on it does so in spite of the patient's efforts, and with the characteristics of an obsession. ... [T] The first phantasies of the kind were entertained very early in

38 Anna had been the lure, the (withheld) gift, in several psychoanalytic transactions at the time: Otto Rank and Sandor Ferenczi all imagined that they were being groomed to become Anna's husband and thus Freud's son-in-law and heir apparent (see Roustang:10). Ernest Jones, too, was later (1914) tempted by such phantasies (cf. Gay:433). Whether or not Freud tacitly indulged these phantasies of his disciples, he was already well aware of the consequences for the daughter of a father "handing her over" to another man-even if the requirements of theory led him to look beyond such venal maneuvers; $c f$. the Dora case (Freud 1905b).

39 Anna Freud's biographer, Elizabeth Young-Bruehl, does note that the "sixth patient is not directly described at all, and this may signal that Freud protected his daughter's privacy with silence" (104). 
life: ... not later than the fifth or sixth year" (179). While the obsessive masturbatory scene and age of the patient resonates with Hans's situation, ${ }^{40}$ there are other aspects of her pathology that recall in particular the denials that had shaped Freud's analysis. Freud describes a "complication" that develops among the girls who have beating phantasies: "When they turn away from their incestuous love for their father, with its genital significance, they easily abandon their feminine role. They spur their 'masculinity complex' ... into activity, and from that time forward only want to be boys" (191). Despite this masculine identification, such a girl does not, Freud points out almost defensively, adopt either masculine behavior or homosexual object-choice. Indeed she "escapes from the demands of the erotic side of her life altogether" (199) but not from her father (200). The boy, by contrast, "who has tried to escape from a homosexual objectchoice, and who has not changed his sex, nevertheless feels like a woman in his conscious phantasies, and endows the women who are beating him with masculine attributes and characteristics" (200); indeed, from its onset the boy's unconscious phantasy "is derived from a feminine attitude towards his father" (198). Freud emphasizes that "in both cases, the beating-phantasy has its origin in an incestuous attachment to the father" (198; emphasis in original).

The positions of Herbert Graf and Anna Freud at the time of analysis share much in common. Both are suffering from neurotic symptoms, both are caught in the throes of problems of judgment: in Herbert's case, the epistemic/narcissistic crisis over the existence of the maternal penis; in Anna's, the crisis over masculine or feminine career paths. That is, both were unable to resolve the castration complexes of their respective genders. Both are adopting nonnormative sexualities. And both are attached to their fathers.

In "A Child Is Being Beaten," as in earlier case studies from Leonardo to the Wolf Man, Freud had recognized males adopting the feminine attitude (what he would later call the negative Oedipus) that he did not-or could not-in the case of Little Hans. Yet Freud's investment in Herbert Graf differed from that in his other patients. As with Anna's situation, Freud-as both adopted father and through Max Graf's procuring a prospective father-in-law-had to bear some responsibility for Herbert's pathology and sexuality. These pathological and relational parallels suggest that in analyzing his daughter Freud experienced the case of his adopted son redivivus. Through deferred action he recognized in Anna's passive masculine identification the passive feminine identification that he had denied Hans (i.e., Herbert) in "Analysis."

40 They also share sadistic components that are not addressed here. 
Hans's return would be played out, however, on another stage. While writing "'A Child Is Being Beaten," 41 Freud was also preparing "a second edition of Leonardo, the only truly beautiful thing I have ever written," as he relates to Lou Andreas-Salomé on 9 February (Freud and AndreasSalomé:90). To the third section of the "Leonardo" essay Freud makes a curious addition. In that chapter, as noted above, Freud discusses infantile sexual theories and the castration threat with extensive references to Hans's contributions, etiologies of male homosexuality-in particular, the revulsion toward the castrated woman, on the one hand, and identification with the mother, on the other hand-and the repudiation of sexuality. At the moment when enlightenment is achieved about the "uncanny and intolerable idea" of woman's castration causing the boy to fear for his masculinity and despise those who have lost theirs, Freud adds in 1919 a footnote that offers an "inescapable" but also besides-the-point conclusion. It connects antisemitism to the unconscious equation of circumcision with castration and thereby hearkens back to the case of Little Hans and its no less anomalous footnote.

\section{DEFERRED ACTION AS DISPLACED RESPONSIBILITY}

When Freud concludes "Analysis," he argues that "Strictly speaking, I learnt nothing new." He goes on, however, to indicate that the analysis has provided "a type and a model." Its typicality and exemplarity lay not in its symptoms but in their formation: "that the multiplicity of the phenomena of repression exhibited by neuroses and the abundance of their pathogenic material do not prevent their being derived from a very limited number of processes concerned with identical ideational complexes" (1909a:147). And the specific ideational complex addressed by the analysis is the castration complex, which by the end of Freud's career explicitly-but here implicitly-becomes the "bedrock," the foundation of all development. At the time of the writing, the castration complex had a competitor for primacy: the primal scene in which the child observes parental intercourse. In 1909 Freud still desires the realia that had been lost with the virtual abandonment of the so-called seduction theory-that neuroses were the consequence of actual sexual assaults by parental figures during childhood-a decade earlier; he desired that objective, factual, external cause that would justify his science as science. There is contextual evidence of its existence in the Graf residence: Herbert did not leave the parental bedroom until after his sister was born. Explaining Little Hans's neurosis as a deferred

41 Freud informed Ferenczi on 24 January 1919 that he was working on the paper that would bear the title "'A Child Is Being Beaten," when completed in mid-March of that year. See editor's note to the paper (1919a:177). 
effect of witnessing the primal scene would exculpate Freud from responsibility. On the other hand, to claim the primal scene would publicize the sexual indiscretions of a male colleague. In "Analysis" he both acknowledges his suspicion but allows the colleague first denial: "Hans's father was unable to confirm my suspicion that there was some recollection stirring in the child's mind of having observed a scene of sexual intercourse between his parents in their bedroom. So let us be content with what we have discovered" (135-136).

The specific threat of castration does also offer that realia. Further he is able to locate the inciting incident with the mother and not the everpresent, albeit never mentioned, reminder of Freud's advice. Still, in his final discussion he universalizes the castration complex as a developmental structure; hence, it is not contingent on threat or chance observation. He can again thereby let himself off the hook.

Ultimately, despite evidence to the contrary, Freud declares Hans normal. No harm done, no blame taken. Indeed, Hans's adventures in neurotica have been to his advantage. Culminating his analysis, Freud declares: "I can therefore well imagine that it may have been to Hans's advantage [heilsam] to have produced this phobia.... It may be that Hans now enjoys an advantage[voraushaben vor] over other children, in that he no longer carries within him that seed $[\mathrm{Keim}]$ in the shape of repressed complexes which must always be of some significance for a child's later life, and which undoubtedly brings within it a certain degree of deformity of character [Charakterverbildung] if not a predisposition to a subsequent neurosis" (143-144). In this concluding offer of restitution for the unintended consequences of Hans's unacknowledged circumcision, Freud returns to this case's primal scene. In describing the beneficial effects of overcoming neurosis he reiterates his earlier charge to Max Graf: "If you do not let your son grow up as a Jew . . . you will deprive him of those sources of energy which cannot be replaced by anything else. He will have to struggle as a Jew, and you ought to develop in him all the energy he will need for the struggle. Do not deprive him of that advantage." In this concluding narrative, overcoming neurosis has accomplished what its genetic cause (i.e., being circumcised) was supposed to have done. Freud has been vindicated. Thanks to his struggle (with neurosis) Hans-Herbertcould become a "fighting Jew."

\section{REFERENCES}

Anzieu, Didier Freud's Self-Analysis. Trans. by Peter Graham. London: 1986 [1975] Hogarth. 
Berman, Marshall All That Is Solid Melts into Air: The Experience of Mo1988 dernity. New York: Penguin.

Blüher, Hans Die deutsche Wandervogelbewegung als erotisches Phä1918 [1911-12] nomen: Ein BeitragzurErkenntnis der sexuellen Inversion. 3rd ed. Berlin: Verlag Hans Blüher.

Boyarin, Daniel Unheroic Conduct: The Rise of Heterosexuality and the 1997 Invention of the Jewish Man. Berkeley/Los Angeles: University of California Press.

Cournut-Janin, Monique, and Jean Cournut 1993

"La castration et le féminin dans les deux sexes." In $\mathrm{La}$ castration et le féminin dans les deux sexes. Ed. by Paul Denis and Claude Janin. Special issue of Revue française de psychanalyse 57: 1353-1558.

Cuddihy, John Murray 1974 The Ordeal of Civility: Freud, Marx, Lèvi-Strauss and the Jewish Struggle with Modernity. New York: Basic Books.

Davis, Whitney Drawing the Dream of the Wolves: Homosexuality, Inter1995 pretation, and Freud's "Wolf Man." Indianapolis: Indiana University Press.

De Carvalho-Ribeiro,

"Oedipe et castration selon le petit Hans." Psychanalyse Paulo 1993

Eilberg-Schwartz, Howard d̀ l'université 18: 47-69. 1994

Ferris, Paul Dr. Freud: A Life. London: Sinclair-Stevenson. 1997

Fleming, Lydia Freud et ses patients. Paris: Hachette. 1986

Fraenkel, Josef 1964

"Freud as a Jew." New York Times Book Review (9 January):30.

"Professor Freud and the Student Society 'Kadimah"' The Gates of Zion (April): 16.

Frankiel, Rita V. "Analysed and Unanalysed Themes in the Treatment of 1992 Little Hans." International Review of Psycho-Analysis 19: 323-333.

Freud, Ernest L. $\quad$ Letters of Sigmund Freud 1873-1939. Trans. by T. and 1961 J. Stern. London: Hogarth.

Freud, Martin Sigmund Freud: Man and Father. New York: Jason 1958 Aronson.

1967 “Who Was Freud?" In The Jews of Austria. Essays on Their Life, History and Destruction. Ed. by Josef Fraenkel. London: Valentine Mitchell. 
Freud, Sigmund 1900 [1953-74]
The Interpretation of Dreams. In vols. 4-5 of The Standard Edition of the Complete Psychological Works of Sigmund Freud. Ed. by James Strachey et al. 24 vols. London: Hogarth.

1905a Three Essays on the Theory of Sexuality. S.E. 7.

1905b Fragment of an Analysis of a Case of Hysteria. S.E. 7.

1907 “The Sexual Enlightenment of Children." S.E 9.

1908a “On the Sexual Theories of Children." S.E. 9.

1908 b "Family Romances." S.E. 9.

1909a "Analysis of a Phobia in a Five-Year-Old Boy." S.E. 10.

1909b “A Case of Obsessional Neurosis." S.E. 10.

1910 "Leonardo da Vinci and a Memory of His Childhood." S.E. 11.

1911 "Psycho-Analytic Notes on an Autobiographical Account of a Case of Paranoia (Dementia Paranoides)." S.E. 12 .

1912-13 Totem and Taboo. S.E. 13.

1919a “A Child Is Being Beaten"” S.E. 17.

1919b "The Uncanny." S.E. 17.

1922a “Medusa's Head.” S.E. 18.

1922b Inhibitions, Symptoms and Anxiety. S.E. 20.

1926 “Address to the Members of the B'nai B'rith." S.E. 20.

1927 “Fetishism” S.E. 21.

1937 “Analysis: Terminable and Interminable." S.E. 23.

1939 Moses and Monotheism. S.E. 23.

1963 The Sexual Enlightenment of Children. Ed. by Philip Rieff. New York: Collier.

n.d. "Aus älteren Aufzeichnungen von 1897 an." Holograph manuscript and transcription in container B28, Sigmund Freud Collection, Library of Congress.

Freud, Sigmund, and Karl Abraham

1965

Freud, Sigmund, and Lou Andreas-Salomé

A Psycho-analytic Dialogue: The Letters of Sigmund Freud and Karl Abraham 1907-1926. Ed. by Hilda C. Abraham and Ernst L. Freud. Trans. by B. Marsh and H. C. Abraham. New York: Basic Books.

Letters. Ed. by Ernst Pfeiffer. Trans. by William and Elaine Robson-Scott. New York: Norton. 
Garrison, Marsha 1978

Gay, Peter 1988

Geller, Jay 1993

1994

1994

"A New Look at Little Hans." Psychoanalytic Review 65:523-532.

Freud: A Life for Our Time. New York: Norton.

"A Paleontological View of Freud's Study of Religion: Unearthing the Leitfossil Circumcision." Modern Judaism 13:49-70.

"Freud v. Freud: Freud's Readings of the Denkwürdigkeiten eines Nervenkranken." In Reading Freud's Reading. Ed. by Sander Gilman, Jutta Birmele, Jay Geller, and Valerie Greenberg. New York: New York University Press.

1997 'Identifying 'Someone who is himself one of them': Recent Studies of Freud's Jewish Identity." Religious Studies Review 18:323-331.

n.d. "The Remains of the Day: Weisswashing the Dream of Irma's Injection." Unpublished ms.

Gilman, Sander 1991

1993a The Case of Sigmund Freud: Medicine and Identity at the Fin de Siecle. Baltimore: Johns Hopkins University Press.

1993b Freud, Race, and Gender. Princeton: Princeton University Press.

Glenn, Jules 'Freud's Advice to Hans' Father: The First Supervisory 1980 Sessions" and "Integrative Summary." In Freud and His Patients, 121-127 and 128-134. Ed. by Mark Kanzer and Jules Glenn. New York: Jason Aronson.

Graf, Max "Reminiscences of Professor Sigmund Freud." Psycho1942 analytic Quarterly 11: 465-476.

Grosser, Paul E., and Edwin Halperin 1979

Grubrich-Simitis, Ilse 1996 [1993]

Harrowitz, Nancy A., and Barbara Hyams, eds. 1995
Anti-Semitism: The Causes and Effects of a Prejudice. Secaucus, NJ: Citadel.

Back to Freud's Texts: Making Silent Documents Speak. Trans. by Philip Slotkin. New Haven: Yale University Press.

Jews and Gender: Responses to Otto Weininger. Philadelphia: Temple University Press. 
Heller, Peter 1981

Horkheimer, Max, and Theodor W. Adorno 1972 [1944]

Katz, Jacob 1982

Koestenbaum, Wayne 1989

Kraus, Karl 1906

Laplanche, Jean 1980

Laplanche, J., and

J.-B. Pontalis 1973 [1967]

Le Rider, Jacques 1982

1993 [1990]

Mosse, George L. 1996

Nandy, Ashis 1983

Nordau, Max 1909a[1898]

1909b[1900]

Nunberg, Herman, and Ernst Federn, eds.

1962-75

Pulzer, Peter 1964

Rank, Otto 1909
"A Quarrel over Bisexuality." In The Turn of the Cen tury, 87-115. Ed. by G. Chapple and H. Schulte. Bonn: Bouvier.

"Elements of Antisemitism." In Dialectics of Enlightenment. Trans. by John Cumming. New York: Seabury.

From Prejudice to Destruction: Anti-Semitism, 17001933. Cambridge: Harvard University Press.

"Privileging the Anus: Anna O. and the Collaborative Origin of Psychoanalysis." In Double Talk: The Erotics of Male Literary Collaboration. New York: Routledge.

“Weib und Kultur." Die Fackel 213 (11 December):5.

Problématiques II / Castration-Symbolisations. Paris: Presses Universitaires de France.

The Language of Psycho-Analysis. Trans. by D. Nicholson-Smith. New York: Norton.

Le Cas Otto Weininger: Racines de l'antiféminisme et l'antisémitisme. Paris: Presses Universitaires de France.

Modernity and Crises of Identity: Culture and Society in Fin-de-Siècle Vienna. Trans. by Rosemary Morris. New York: Continuum.

The Image of Man: The Creation of Modern Masculinity. New York: Oxford University Press.

The Intimate Enemy: Loss and Recovery of Self under Colonialism. Delhi: Oxford University Press.

"II. Kongressrede." In Zionistische Schriften, 58-76. Ed. by Zionistisches Aktionskomitee. Cologne/Leipzig: Jüdischer Verlag.

“Muskeljudentum.” In Zionistische Schriften, 379-381.

Minutes of the Vienna Psychoanalytic Society. Trans. by M. Nunberg with H. Collins. Vol. 1 of 4 . New York: International Universities.

The Rise of Political Antisemitism in Germany and Austria. New York: Wiley.

Der Mythus von der Geburt des Helden. Leipzig/ Vienna: Deuticke. 
1981 [1905] “The Essence of Judaism.” In Dennis Klein, Jewish Origins of the Psychoanalytic Movement, 170-173.New York: Praeger.

Reik, Theodor Der eigene und der fremde Gott. Leipzig: Internationaler

1923 Psychoanalytischer Verlag.

1954 "Freud and Jewish Wit." Psychoanalysis 2:12-20.

Rice, Emmanuel Freud and Moses: The Long Journey Home. Albany:

1990 State University of New York Press.

1994 "The Jewish Heritage of Sigmund Freud." Psychoanalytic Review 81: 237-258.

Robert, Marthe From Oedipus to Moses: Freud's Jewish Identity. Trans. 1976 [1974] by Ralph Manheim. Garden City, NY: Anchor.

Roustang, François Dire Mastery: Discipleship from Freud to Lacan. Trans. 1982 [1976] by Ned Lukacher. Baltimore: Johns Hopkins University Press.

Rubenstein, Richard

After Auschwitz: Radical Theology and Contemporary 1966 Judaism. Indianapolis: Bobbs-Merrill.

Rudnytsky, Peter L.

"'Mother, have you got a wiwimaker too?' Freud's Rep1994 resentation of Female Sexuality in the Case of Little Hans." In One Hundred Years of Psychoanalysis. Contributions to the History of Psychoanalysis, 121-133. Ed. by André Haynal and Ernest Falzeder. London: Karnac Books.

Santner, Eric L. $\quad$ My Own Private Germany: Daniel Paul Schreber's Secret 1996 History of Modernity. Princeton: Princeton University Press.

Silverman, Martin "A Fresh Look at the Case of Little Hans." In Freud and 1980 His Patients. Ed. by Mark Kanzer and Jules Glenn. New York: Jason Aronson.

Sprengnether, Madelon

The Spectral Mother: Freud, Feminism, and Psycho1990 analysis. Ithaca: Cornell University Press.

Strauss, Herbert A., International Biographical Dictionary of Central Euroand Werner Röder, pean Emigrés 1933-1945. Vol. 2, part 1: A-K The Arts, eds. Sciences, and Literature. München/New York/London/ 1983 Paris: K. G. Saur.

Tractenberg, Moises "Circumcision, Crucifixion, and Anti-Semitism: The 1989 Antithetical Character of Ideologies and Their Symbols Which Contain Crossed Lines." International Review of Psycho-Analysis 16:459-471. 
Weininger, Otto Geschlecht und Charakter. Vienna: W. Braumüller. 1903

Wistrich, Robert The Jews of Vienna in the Age of Franz Joseph. Oxford: 1989 Oxford University Press.

Yerushalmi, Yosef Freud's Moses: Judaism Terminable and Interminable. 1991 New Haven: Yale University Press.

Young-Bruehl, Anna Freud. New York: Summit.

Elizabeth

1988 